\title{
Evaluating the Spatial Variability of Soils of Similar Lithology under Different Land Uses and Degradation Risks in a Guinea Savanna Agro-Ecology of Nigeria
}

\author{
Peter IkemefunaEzeaku \\ Department of Soil Science, Faculty of Agriculture, University of Nigeria, Nsukka, Nigeria.
}

\begin{abstract}
$\overline{\text { Abstract:The spatial variability of soils of similar lithology, which may be greatly affected by land use, plays }}$ an important role in both agriculture and the environment, especially with regard to soil fertility and soil quality. Little research has been done in this regard. The study addresses the spatial pattern of soil properties under different land use types and their degradation ratesin Guinea Savanna agroecology of Nigeria. 112 soil samples (between $0-20 \mathrm{~cm}$ and $20-45 \mathrm{~cm}$ depths)were collected, using a grid sampling design, from arable, plantation crops and fallow sites in Agyaragu and Shabu locations in Nasarawa State, Nigeria. Using statistical method, the soils were characterized and compared for the spatial heterogeneity of Ksat, texture, soil pH, SOM and CEC under different land use types(LUTS)(farmland, plantation and fallow). Using a rating scheme, soil degradation risks of these soil properties were determined.Results revealed significant $(P<0.05)$ spatial changes in soil properties at varying degrees. LUTs had no effect on soil texture, while silt/clay ratio varied from less than unity to greater than unity. Bulk density and Ksat values were low to high. Soil chemicals spatially varied and their interactions with management practices significant $(P<0.05 \%)$. Soil degradation risks (vulnerability potential) showed thatsoil qualities decreased in the order: $\mathrm{pH}\left(\mathrm{H}_{2} \mathrm{O}\right)(\mathrm{SDR}=1)>$ bulk density and Ksat (SDR $=2)>$ texture and available $P(S D R=3)>S O M$, total $N$ and $C E C(S D R=4)$. Best soil quality had a value of $S D R$ (1) and the least had a value of SDR (5). Soils at Agyaragu are slightly more prone to resist degradation (mean $S D R=3.0$ ) and thus better soil qualities than those of Shabu (mean SDR = 3.4). Study concludes that spatial patterns of the considered soil propertieswould change significantly with land use changes currently being implemented to achieve sustainable agriculture. Taking LUT into account when considering the spatial variation of thesoil properties would increase the accuracy in prediction of soil nutrient status and nutrient vulnerability in the Guinea savanna agroecology of Nigeria.
\end{abstract}

Keywords: Land use types, degradation, spatial variability, guinea savanna, Nigeria.

\section{Introduction}

In the tropics, many different soil types occur as a result of a combination of pedogenic factors such as climate, topography, parent materials, disturbance history and soil forming processes like pedoturbations. Varied landscape structures arising there-from characterize soil property variations both laterally and vertically in most agricultural sites in savanna ecology.

Sustaining agricultural productivity and bio-activity is a function of soil bio-physical and chemical properties (soil quality indicators). But the inability of the soil quality indicators to perform optimally in terms of increasing productivity, especially in savanna agroecologies, has been related mostly to soil degradation (Ezeaku and Salau, 2005). Ezeaku et al. (2008) defined soil degradation by erosion processes (wind and/or water) as the lowering of soil physical and chemical fertility to a threshold that limits maximization of agricultural productivity. Reports by Greenland (1981), Ogunkule et al. (1994), Chicacek and Umer (1999), and Pando et al. (2004) have shown that nutrient mining, absence of fallow periods, use of inappropriate farming practices and frequent changes in land uses (over-cultivation), variation in micro-climate, vegetation, parent material, and crops grown escerbate degradation, resulting to constant plummeting of soil fertility levels and productivity.

Assessment of soil quality and productivity in various agricultural management systems involves essentially the use of bio-physical and chemical soil attributes (Doran and Pakin, 1994; Lal, 1994), but the complexity of these properties and their interactions in addition to other environmental variables make the study of crop response to soil very difficult (Olsen, 1981).

The upsurge interest in the heterogeneity and variability of soil physicochemical properties in the field and their relationship with soil productivity started with the reports at different times and on macro-scale of tropical soils (Tomlinson, 1970; Beckett and Webster, 1982) and inter-tropical areas (Kang, 1978; Moorman and kang, 1978; Lal, 1990). Reports on recurrent variations on the scale of a single field under varying land uses have been scanty, especially in Nigeria. However, few instances include the reports by Ogunkule (1986) and Fasina (2002) for southwest; Asadu et al. (1997) andEzeaku et al. (2002) for southeast and Areola (1982) for 
northcentral Nigeria. All these reports show that soil and crop variability are mostly observed in the fields where fertilities are low and according to Akinride et al., (2000) where there is practice of more than one kind of land use within an area.

Currently, there is a lack of detailed information about soil variability and its effect on land use types around the study areas typified by fragile savannah ecosystem. Also lacking is information on the extent of potential degradation (vulnerability) of soil qualities. Therefore, knowledge of the degree of variability of soil properties and their interaction with land use types as well as degradation risks of the soil qualities has become essential for both practical and experimental agriculture.

The objectives of this study were to: (i) evaluate the spatial variability of soil properties of similar lithology; (ii) determine the interaction levels between the soil quality indicators and the land use type management practices; (iii) provide an understanding of the potential soil quality degradation rates, and (iv) suggest appropriate practices for sustainable management.

\subsection{Site description}

\section{Materials and Method}

Agyaragu and Shabu locations in Nasarawa State are situated in Guinea Savanna Agroecology of Nigeria. They are located by $6^{\circ} 15^{\prime} \mathrm{N}$ and $9^{\circ} 30^{\prime} \mathrm{E}$ and $11^{\circ} 00^{\prime} \mathrm{E}$ with analtitude range between sea level and 600 $\mathrm{m}$ (Obaje et al., 2005). . The general climate is tropical, having distinct rainy with clear and dry seasons. The mean temperature ranges between 23.5 and $30.9^{\circ} \mathrm{C}$, while mean annual rainfall ranges between 1270 and 1530 $\mathrm{mm}$ with a 3-4 month dry season (November to March). They are agricultural areas generally characterized by gentle, undulating plains and upland-inland continuum. The areas are drained by many rivers and streams. The soils are moderately deep with little mixing of stones in the surface horizons. The dominant land uses are plantation (e.g. oranges, mango) agriculture, cereal and arable cropping systems (Ezeaku et al., 2005).

The study areas were particularly chosen for this study because of their prime place in staple food crops production in Nasarawa State, the latter depicting a true agrarian setting in Nigeria. The State has the acronym 'Food basket' of Nigeria.

\subsection{Site characterization}

Each study area was divided into $0.7 \mathrm{~km}$ grid and after which 7 grids were randomly chosen for soil sampling based on the initial baseline assessment and characterization information on dominant land uses and their intensity, crop management and topographic features (upland, middle slope and lowland) as shown in Table 1 .

\subsection{Soil sampling and Laboratory analysis}

Soils of the two locations were sampled within each field at two repeated measures. Arable crops were planted by farmers at the on-set of rains (April/May), while plantation crops were earlier established. Soil sampling was in June (4 weeks after planting- WAP) and September/October (8-12 WAP) at grid size of 3x4m in each arable land use and $7 \times 10 \mathrm{~m}$ in each fallow and plantation LUT. Total grid size for each location soil samples was $0.632 \mathrm{~km}\left(316 \mathrm{~m}^{2}\right.$ each).

In each arable LUT, 48 random auger (with an internal diameter of $65 \mathrm{~mm}$ ) samples (RAS) were collected from $0-15 \mathrm{~cm}$ and $15-30 \mathrm{~cm}$ depths whereas 64 RAS were collected from $0-20 \mathrm{~cm}$ and $20-45 \mathrm{~cm}$ soil depths in the six plantation crops and 2 fallow sites in both locations. Also, 28 undisturbed core(of a known volume $-96.6 \mathrm{~cm}^{3}$ ) samples were randomly collected from all the land use types

Prior to sampling, the cylinder was fitted with a dolly that protect the rim from being distorted and to enable the corer to be driven easily into the ground with a sledge hammer until it flushes with the soil surface. Soil samples were removed from the steel collection augers and air dried. The dried samples were gently disaggregated and mixed with a mortar and pestle. The sample was then passed through a 2-mm screen and the coarse fraction $(>2 \mathrm{~mm}$ ) separated. The $<2 \mathrm{~mm}$ soil fraction was ground in a mill to a fine powder. All samples were stored in suitable polythene receptacles.

\subsection{Laboratory analyses methods}

The analytical characteristics of the soil samples were determined in the following manner. Physical properties:

2.4.1 Soil texture: The percentage by weight of gravel, sand, silt, and clay (particle size diameter $<2 \mathrm{~mm}$ ) was obtained by hydrometer method (Gee and Bauder, 1986). The hydrometer method of silt and clay measurement relies on the effects of particle size on the differential vertical velocities of the particles through a water column (i.e. the sedimentation rate). Sedimentation rate is dependent upon the liquid temperature, viscosity, and the diameter and specific gravity of the falling soil particles. 
Soil was dispersed into individual particles after pretreatment with hydrogen peroxide to destroy the organic matter, and addition of sodium hexametaphosphate solution to aid dispersion, then dispersed throughout a water column and allowed to settle. Hydrometer measurements quantified the amount of material remaining in suspension at specific time intervals. This was then related to the amounts of sand, silt and clay in the soil.

2.4.2 Bulk density: Soils on an undisturbed cylindrical core (volume $96.6 \mathrm{~cm}^{3}$ ) taken at field-moisture conditions was determined for bulk density on an oven-dried weight basis, and particle density with a pycnometer (Blake and Hartge, 1986).

2.4.3 Hydraulic conductivity (Ksat):This was determined based on method by Wooding (1968).

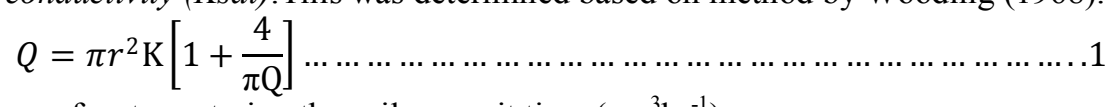

Where $\mathrm{Q}=$ volume of water entering the soil per unit time $\left(\mathrm{cm}^{3} \mathrm{hr}^{-1}\right)$

$\mathrm{K}=$ hydraulic conductivity $\left(\mathrm{cmhr}^{-1}\right)$

$=$ is a parameter

It was assumed that unsaturated hydraulic conductivity of soil varies with matric potential $\mathrm{h}(\mathrm{cm})$ as proposed by Gardner (1958).

$$
K(h)=K \operatorname{satexp}(\alpha h)
$$

Where $\mathrm{h}=$ matric potential or tension at the water source

$\mathrm{K}_{\mathrm{sat}}=$ Saturated hydraulic conductivity

$\mathrm{K}$ in equation 1 was replaced by $\mathrm{K}_{\text {sat }} \exp (\alpha h)$ and substituting of $\mathrm{h}_{1}$ and $\mathrm{h}_{2}$ gave:

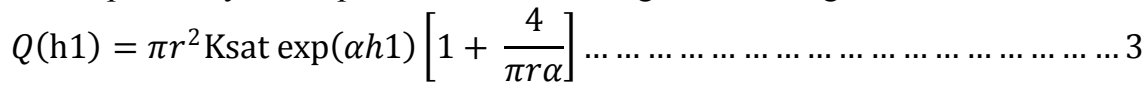

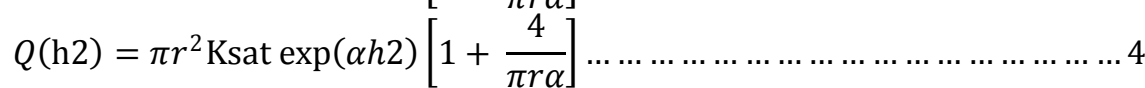

Dividing equation 4 by 3 and solving for _ yields:

$$
\alpha=\frac{\operatorname{In}\left[\frac{Q(h 2)}{Q(h 1)}\right]}{h 2-h 1}
$$

Since $\mathrm{Q}\left(\mathrm{h}_{1}\right)$ and $\mathrm{Q}\left(\mathrm{h}_{2}\right)$ were measured, and $\mathrm{h}_{1}$ and $\mathrm{h}_{2}$ were known, was computed directly from equation 5 .

With _ known, it was possible to calculate Ksat from equation 3 or 4

Chemical properties:

2.4.4 Soil $p H$ was determined in duplicate both in distilled water and in $0.1 \mathrm{~N} \mathrm{KCl}$ solution, using a soil/liquid ratio of 1:2.5. After stirring for 30 minutes the $\mathrm{pH}$ values were read off using a glass electrode $\mathrm{pH}$ meter (Mclean, 1982);

2.4.5 Organic carbon $(O C)$ was obtained by the wet dichromate acid oxidation method (Nelson and Sommers, 1982); percentage organic matter was calculated by multiplying the value for organic carbon by the "Van Bemmler factor" of 1.724 , which was based on the assumption that soil organic matter contains $58 \% \mathrm{C}$.

2.4.6 Total nitrogen was determined using the kjeldhal distillation method as described by Bremmer and Mulvaney (1982). The ammonia from the digestion was distilled with $45 \% \mathrm{NaOH}$ into $25 \%$ boric acid and determined by titrating $0.05 \mathrm{~N} \mathrm{KCl}$.

2.4.7 Available phosphorus was obtained using Bray 1 bicarbonate extraction method as modified by Olsen and Sommers (1982). Many extraction techniques for plant-available phosphate have been developed. The modified Olsen extractant is convenient for routine use.

2.4.8 Exchangeable basic cations $\left(\mathrm{Ca}, \mathrm{Mg}, \mathrm{Na}\right.$ and $\mathrm{K}$ ) were extracted in ammonium acetate $\left(\mathrm{NH}_{4} \mathrm{OA}\right)$, calcium and magnesium were determined using ethylene diamine tetraacetic acid (EDTA) titration method while potassium and sodium were determined colorimetrically using flame photometer (Rhoade, 1982a).

2.4.9 Cation exchange capacity was determined titrimetically using $0.01 \mathrm{~N} \mathrm{NaOH}$, while Base saturation was computed as the percentage ratios of exchangeable bases.

2.5 Statistics: Data generated were subjected to analysis using statistical package for agricultural sciences (SAS Institute, 2000).Land use types and management practices were regressed.Correlation analysis was carried out to determine the associations between variables. The least significant difference $\left(\mathrm{LSD}_{0.5}\right)$ was used to determine the differences between the different land use practices (Hoshmand, 1994) based on the several soil physical and chemical properties.

Variability was obtained as a function of mean and standard deviation values of the soil properties in the statistical sample populations. They were derived by the following functions:

Population sample $(n)=X_{1}, X_{2} \ldots X_{n}$;

Mean $\left(\mu_{\epsilon}\right)=\frac{\sum X n}{n}$ (to estimate average value of the parameter);

Standard deviation $\left(\sigma_{\epsilon}\right)=\frac{\sum\left(X_{i}-\mu_{\epsilon}\right) 2}{(n-1) 1 / 2}$ (to give range or scatter of the parameter) 
Coefficient of variation $(C V)=\left(\frac{\sigma}{\mu}\right) 100 \%$ (to express variability on a relative scale).

\subsection{Soil degradation rating (SDR)}

The rating scheme for soil degradation (SDR) developed by Lal (1994) based on several soil properties was applied in this study. Vulnerability potential $(\mathrm{Vp})$ of the soil qualities was added to the scheme. Soil bulk density, saturated hydraulic conductivity (Ksat), soil texture, soil organic carbon (SOM), CEC, available P and soil $\mathrm{pH}$ were selected for the rating because they have been considered as important measures of soil quality that determine soil productivity (Doran et al., 1994).The critical levels of the soil qualities were weighted on a scale of 1 to 5. In SDR, a weight of 1 was given when there were no limitations and 5 were given when the limitation was extreme (Table 2). Reverse was the case for Vp values. In this way, good soils have the least SDR and poor soils have the highest whereas in Vp good soils have the highest value (5) and least value (1) for poor soils. With this arrangement, the obtained SDR rate was applied to correspond reversely with vulnerability potential. Determining the SDR of the selected soil parameters was based on the established critical levels of soil elements from various literatures (Adepetu et al., 1979; Adeoye et al., 1984; Landon, 1984; Enwezor et al., 1989; Isirimah et al., 2003; Lal, 1994).

\subsection{Site characterization}

\section{Results and Discussion}

Characterization induced information on soil texture, description of land use and crop management as well as topographic features are shown in Table 1 for both locations. The results show that Yam/Cassava, Maize/Cowpea and Orange orchard LUTs aresituated at upper slopes of the landscape at Agyaragu.Oil palm plantation is located at the middle slope, while Cocoyam and Banana/Plantain LUTs are located at the lower slopes. The age of the LUTs varies from 2.6 months to 6 years, while management practices ranged from addition of N.P.K fertilizers through organic materials to mulching.

At Shabu, the LUTs are found in only two physiographic units: Upper slopes (Yam/Cassava, Maize/Millet and Cashew/Orange orchard), and lower slopes (Rice, Banana/Plantain and Bambo) (Table 1). Age of the LUTs ranges from 2 months to 11years and management practices include chemical fertilization, mulching, poultry manuring and farm yard manure. Only Bambo LUT is managed by incremental harvesting; yearly harvest for staking and 2 or more years for roofing.

\subsection{Soil property variations}

Results of soil physical property variations at the locations are shown in Table 3. It reveals that soil texture rangesin both locations are predominantly sandy loam, reflecting soils from sandstone. Sandy loam characteristic is an indication of the soils' similarity in lithological origin, because a report by Obaje et al. 2005) has shown that sand stones have parent materials of cretaceous sediments.

Table 1: Landuse types (LUT) in various physiographic units at Agyaragu and Shabu locations.

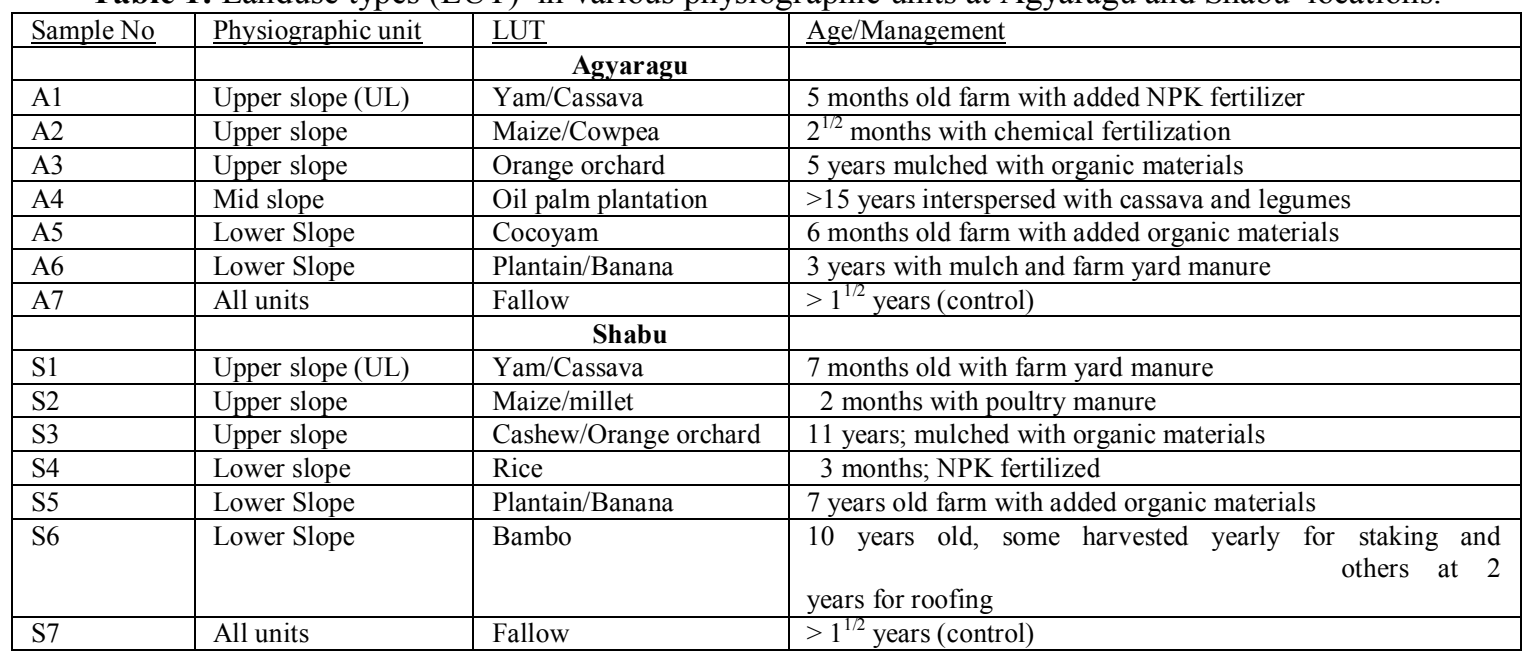

Silt/clay ratio vary between 0.3 and $24(\mathrm{CV}=4.13 \%)$ with Orange orchard land use being significantly $(\mathrm{P}<0.05)$ higher than other LUTs at Agyaragu (Table 3). At Shabu, the range isfrom 0.3 to $3.0(\mathrm{CV}=11.2 \%)$ but lower in Bambo and Cashew/Orange orchards. Averaging the values over each location, mean values for Agyaragu( 0.93$)$ and Shabu (0.89) were almost similar but are less than unity. Nwaka and Kwari (2000) report shows that 
silt/clay ratio less than unity indicate low values, signifying high weatherability of the soils and pedogenesis under land uses.

Table 2: Rating scheme for Soil Degradation Rating (SDR) and Vulnerability potential (Vp)

\begin{tabular}{|l|l|l|l|}
\hline${ }^{*}$ SDR Limitation & Relative weighting scale (RWS) & ${ }^{* *}$ Vulnerability potential \\
\hline None & 1 & None & RWS \\
\hline Slight & 2 & Low & 4 \\
\hline Moderate & 3 & Moderate & 3 \\
\hline Severe & 4 & High & 2 \\
\hline Extreme & 5 & Very high & 1 \\
\hline
\end{tabular}

Source: ${ }^{*}$ Lal, (1994), **Author

Result of mean bulk density (Bd) ranges from 1.24 to $1.46 \mathrm{Mgm}^{-3}(\mathrm{CV}=7.1 \%)$ at Agyaragu; and 0.9 to $1.38 \mathrm{Mgm}^{-3}(\mathrm{CV}=9.7 \%)$ at Shabu LUTs (Tables 3). Lower mean value obtained at Shabu (1.24 Mgm $\left.{ }^{-3}\right)$ relative to Agyaragu (1.34 $\mathrm{Mgm}^{-3}$ )could be a result of constant cultivation, high organic matter content due to mulching and addition of other organic materials that biodegraded. This suggests that low bulk density at Shabu soils may not be limiting crop production. However, both mean values $\left(1.24 \mathrm{Mgm}^{-3}\right.$ and $\left.1.34 \mathrm{Mgm}^{-3}\right) \mathrm{of}^{-3}$ the locations are generally low relative to fallow soils(taken as reference conditions) at Agyaragu (1.46 $\left.\mathrm{Mgm}^{-3}\right)$ and Shabu (1.38 $\left.\mathrm{Mgm}^{-3}\right)$.

Following above trend, it might be reasonable to say that both location soils have better structural conditions for crop production. Soils with similar mean density values have been reported elsewhere (Landon, 1984; Lal, 1994) to have subangular blocky structure with very friable consistency morphology suitable for crop growth. Higher bulk densities obtained in both location fallow soils are in tandem with mean values reported for grasslands and rangelands relative to agricultural sites (Neil et al., 1997; Pando et al., 2004).

Results of the soils under the land use types are also shown in Table 3. It reveals that all LUTslocated in lower physiographic units except Bambo land use $\left(0.9 \mathrm{Mgm}^{-3}\right)$ recorded higher bulk density values $\left(>1.35<1.41 \mathrm{Mgm}^{-3}\right)$ than the upper $\left(>1.22<1.35 \mathrm{Mgm}^{-3}\right)$ and midslope LUT soils $\left(1.26 \mathrm{Mgm}^{-3}\right)$ at Shabu. Higher bulk densities observed in lower lands may be associated to colluviation and seasonal flooding of soils by erosion which leads to surface crusting and compaction (Lal, 1990, 1994; Isirimah et al., 2003). Related reports show that continued wetting and drying of soils, especially in lower lands, decrease aggregate stability (Caron et al., 1992) leading to collapse of soil pores and production of finer particles and macro-aggregates that increases density of soils (Levy and Miller, 1997). Scalenge et al., (2004) reported similar higher density on wetted soil when compared with dry soil on a fragipan.

Mean Ksat values varied from 5.91\% (at Agyaragu) to $18.23 \%$ at Shabu, suggesting that Agyaragu LUT soils have moderate conductivity of water, while those of Shabu have very rapid water flow. Landon (1984) reported Ksat values in the range of $0-0.8 \mathrm{Cmhr}^{-1}$ as none water flow, $0.8-2 \mathrm{Cmhr}^{-1}$ (slight), 2-6 $\mathrm{Cmhr}^{-1}$ (moderate), 6-8 $\mathrm{Cmhr}^{-1}$ (moderately rapid), 8-12.5 (rapid), and $>12.5$ as rapid water transmission. The low spatial variability of mean Ksat observed in Agyaragu LUT soils may be associated to higher fewer mobile regions due to plinthite (Bigger et al., 1976) and/or higher clay contents that constrict voids and which can make an area prone to flooding during rainy season, especially in lower physiographies (Swartz et al., 2003).

Contrastly, high mean Ksat values in Shabu LUT soils suggests very high water transmission and this may be due to increases in bioturbation (e.g. burrowing activities by animals and root movement in soil) that result to higher bio-pores and cross-sectional areas that contribute to flow and such soils could be regarded as hydraulically conductive (Ezeaku et al., 2005).

The implication of the low mean Ksat (none water flow) and high (extremewater flow) obtained in both locations is that crop production may be limited. Too little and/or too high water transmission has been reported to limit crop production due to unavailability at the root zone (Ezeaku et al., 2005).

Within the LUT soils, low mean Ksat was observed in Cocoyam, Plantain/Banana at Agyaragu; and Yam/Cassava, Maize/Millet, Cashew/Orange orchard, Rice soils at Shabu. Only soils of Orange orchard LUT has moderate to moderately rapid flow. It may not be surprising that most of the arable LUT soils had low mean Ksat. The crops were mostly cultivated in upland physiographic unit. It has been reported that water moves from high potential to low potential area and as such water flux is in the direction of upland-inland continuum (Bigger et al., 1976).

Results of chemical analysis of both locations are presented in Table 4. Agyaragu soil has mean soil $\mathrm{pH}$ value of 6.6 (range: $5.12-7.41 ; \mathrm{CV} \%=5.4$ ), and that of Shabu 5.6 (range: $5.02-6.15 ; \mathrm{Cv} \%=8.2$ ). Optimum $\mathrm{pH}$ for most agricultural crops falls between 6.0 and 7.0 and nutrients are more available at pH of about 6.5 (Lal, 1994). This indicates that soils at Agyaragu may not generally be limiting crop production, while soils at Shabu present conditions that may limit crop production due probably to Al toxicity. Opara-Nadi (1988) reported that Al toxicity in soils with $\mathrm{pH}$ value of about 5.5 increases in intensity as $\mathrm{pH}$ increases. Based on these, liming is therefore necessary to generally reduce acidity in Maize/Cowpea, Cocoyam, Maize/Millet, Cashew/Orange 
plantation and Rice LUTs as their soil $\mathrm{pH}$ values were generally less than 5.5. Low $\mathrm{pH}$ values obtained may be due to leaching effect of rainfall on the soils and according to Busari et al. (2005) due to the amount of materials removed at previous harvests, amount and type of fertilizer normally used and the amount of leaching that occurs.

Table 3: Physical properties of soils under varying Land use types (LUT) at Agyaragu and Shabu.

\begin{tabular}{|c|c|c|c|c|c|c|c|c|}
\hline $\begin{array}{l}\text { Sample } \\
\text { No }\end{array}$ & LUT & Sand & $\begin{array}{l}\text { Silt } \\
\left(\mathrm{gkg}^{-1}\right)\end{array}$ & Clay & $\begin{array}{l}\text { Silt/Clay } \\
\text { ratio }\end{array}$ & $\begin{array}{c}\text { Ksat } \\
\mathrm{Cmhr}^{-1}\end{array}$ & $\mathrm{Bd} \mathrm{Mgm}^{-3}$ & Texture \\
\hline & & & \multicolumn{6}{|c|}{ Agyaragu } \\
\hline A1 & Yam/Cassava & 740 & 100 & 160 & 0.63 & 3.44 & 1.30 & Sandy loam \\
\hline A2 & Maize/Cowpea & 790 & 06 & 150 & 0.4 & 2.32 & 1.35 & Sandy loam \\
\hline A3 & Orange orchard & 750 & 240 & 10 & 24 & 6.31 & 1.24 & Loamysand \\
\hline A4 & $\begin{array}{l}\text { Oil palm } \\
\text { plantation }\end{array}$ & 800 & 190 & 10 & 19 & 4.63 & 1.26 & Loamy sand \\
\hline A5 & Cocoyam & 580 & 120 & 300 & 0.4 & 0.53 & 1.41 & $\begin{array}{l}\text { Sandy clay } \\
\text { loam }\end{array}$ \\
\hline A6 & Plantain/Banana & 710 & 70 & 220 & 0.32 & 0.75 & 1.38 & $\begin{array}{l}\text { Sandy clay } \\
\text { loam }\end{array}$ \\
\hline A7 & Fallow & 580 & 220 & 200 & 1.1 & 0.29 & 1.46 & $\begin{array}{l}\text { Sandy clay } \\
\text { loam/Loamy } \\
\text { sand }\end{array}$ \\
\hline Mean & & 720 & 140 & 150 & 0.93 & 1.31 & 1.34 & \\
\hline \multirow[t]{2}{*}{$\mathrm{CV}(\%)$} & & 6.46 & 7.11 & 7.70 & 4.13 & 5.91 & 7.1 & \\
\hline & & & \multicolumn{6}{|l|}{ Shabu } \\
\hline S1 & Yam/Cassava & 630 & 180 & 190 & 0.95 & 1.14 & 1.32 & Sandy loam \\
\hline S2 & Maize/millet & 600 & 300 & 100 & 3.0 & 1.00 & 1.33 & Sandy loam \\
\hline S3 & $\begin{array}{l}\text { Cashew/Orange } \\
\text { orchard }\end{array}$ & 710 & 100 & 190 & 0.53 & 1.71 & 1.22 & $\begin{array}{l}\text { Loamy sand } \\
\text { (LS) }\end{array}$ \\
\hline S4 & Rice & 590 & 190 & 220 & 0.86 & 0.77 & 1.36 & $\begin{array}{l}\text { Sandy clay } \\
\text { loam (SCL) }\end{array}$ \\
\hline S5 & Plantain/Banana & 690 & 140 & 170 & 0.82 & 0.80 & 1.35 & Sandy loam \\
\hline S6 & Bambo & 780 & 60 & 200 & 0.3 & 2.65 & 0.9 & Sandy loam \\
\hline S7 & Fallow & 630 & 170 & 200 & 0.85 & 0.58 & 1.38 & SCL/LS \\
\hline Mean & & 660 & 160 & 180 & 0.89 & 0.09 & 1.24 & Sandy loam \\
\hline CV $(\%)$ & & 8.20 & 5.27 & 9.4 & 11.17 & 18.23 & 9.7 & \\
\hline
\end{tabular}

NB: Ksat = saturated hydraulic conductivity, $\mathrm{Bd}=$ bulk density

Soil organic matter (SOM) mean values range from 3.9 to $19.4 \mathrm{gkg}^{-1}($ mean=10.2; $\mathrm{CV}=4.02 \%$ ) at Agyaragu, and 3.1 to $18.5 \mathrm{gkg}^{-1}$ (mean $=8.9 ; \mathrm{CV}=6.3 \%$ ) at Shabu (Table 4). However, averagingthe mean values over each location and comparing with critical value of $30.0 \mathrm{gkg}^{-1}$ for Northern Nigeria (Akinrinade and Obigbesan, 2007) the two locationsmean (10.2 and $\left.8.9 \mathrm{gkg}^{-1}\right)$ fell below the critical value. Value of $30.0 \mathrm{gkg}^{-1}$ was suggested as level to which response to $\mathrm{N}$ fertilization is not expected (Agboola, 1973). The general low levels of SOM may be attributed to management practices involving burning, continuous cultivation with reduced fallow period, and scanty vegetation coverage of the land mass, an indication of low carbon stocks available in soil (Collins et al., 1999).

Total nitrogen followed a similar trend as soil organic matter since soil nitrogen constitutes the bulk of total $\mathrm{N}$ for tropical soils (Noma et al., 2005). Mean total $\mathrm{N}$ for Agyaragu $\left(0.5 \mathrm{gkg}^{-1}\right)$ and Shabu $\left(0.3 \mathrm{gkg}^{-1}\right)$ as well as the values for all the land use types (Tables 4) are below 0.15 percent or $1.5 \mathrm{gkg}^{-1}$, the critical value for tropical soils (Enwezor et al., 1989). This indicates high $\mathrm{N}$ deficiencies. The cause of $\mathrm{N}$ deficiency in the soils may be related to intense leaching and erosion due to rainfall and according to Enwezor et al. (1989) high mineralization rate and crop exports. Thus the low $\mathrm{N}$ levels signify response to $\mathrm{N}$ fertilization.

There were observed variability of exchangeable cation elements $(\mathrm{Ca}, \mathrm{Mg}$, and $\mathrm{K})$ across the cultivated soils (Tables 4). Critical values of 2.0, 0.4 and $0.20 \mathrm{Cmol} \mathrm{kg}^{-1}$ for $\mathrm{Ca}, \mathrm{Mg}$ and $\mathrm{K}$, respectively were reported by Adeoye and Agboola (1984). Agboola and Corey (1974) reported critical value for $\mathrm{Mg}$ as $1.04 \mathrm{Cmolkg}^{-1}$. Obigbesan et al., (1974) and Isirimah et al. (2003) reported critical $\mathrm{K}$ values of between $0.16 \mathrm{Cmol} \mathrm{kg}^{-1}$ and 0.20 $\mathrm{Cmol} \mathrm{kg}{ }^{-1}$ for different land uses in Nigeria. In comparison, mean Ca values obtained in both locations were higher than those reported critical values, suggesting adequate presence of Ca nutrients for crop use in the soils of study. Mean values of $\mathrm{Mg}$ and $\mathrm{K}$ are mostly within the critical limit ranges. However, there were few LUT soils with Mg and $\mathrm{K}$ values slightly above the critical limits. For instance, Cocoyam and Banana/Plantain soils 
have high $\mathrm{K}$ contents relative to other LUT soils at Agyaragu. Similar trend was observed for $\mathrm{Mg}$ in Maize/Cowpea and Rice soils at shabu (Table 4).

Soil cation exchange capacity (CEC) has been classified as low $\left(<6 \mathrm{Cmol} \mathrm{kg}^{-1}\right)$, medium $\left(6-12 \mathrm{Cmol} \mathrm{kg}^{-1}\right)$ and high $\left(>12 \mathrm{Cmol} \mathrm{kg}^{-1}\right.$ ) for some Nigerian soils (Adepetu et al., 1979; Ojanuga and Awojuola, 1981). On the basis of this classification, mean CEC of Agyaragu soils (4.05) and Shabu soils (3.52) (Tables 4) fell within the low to medium class. Low CEC value of tropical soils is due to dominance of kaolinitic clays in the fine earth fraction (Ojanuga et al., 1981). The percentage variation is more in Agyaragu $(\mathrm{Cv}=21.1 \%)$ than at $\mathrm{Shabu}(\mathrm{Cv}=$ 18.1).

Variations in CEC were in an increasing trend of Oil palm plantation, Banana/Plantain, Fallow, Yam/Cassava, Maize/Cowpea, Orange orchard and Cocoyam with 0.64, 0.70, 0.71, 4.8, 5.4, 7.01 and 9.1 Cmol $\mathrm{kg}^{-1}$, respectively,at Agyaragu (Table 4). At Shabu it was in the order of Maize/Millet $\left(0.44 \mathrm{Cmol} \mathrm{kg}^{-1}\right)$, Fallow $\left(0.72 \mathrm{Cmol} \mathrm{kg}^{-1}\right)$, Rice $\left(2.7 \mathrm{Cmol} \mathrm{kg}^{-1}\right)$, Yam/Cassava $\left(3.5 \mathrm{Cmol} \mathrm{kg}^{-1}\right)$, Cashew/Orange orchard $\left(4.7 \mathrm{Cmol} \mathrm{kg}^{-1}\right)$, Banana/Plantain $\left(5.8 \mathrm{Cmol} \mathrm{kg}^{-1}\right)$ and Bambo $\left(7.1 \mathrm{Cmol} \mathrm{kg}^{-1}\right)$.

At Agyaragu, values of available $P$ were in the range of 8.03 and $21.4 \mathrm{mgkg}^{-1}$ with the least observed in Oil palm plantation and largest associated with Fallow LUT. At Shabu, the rangesvary between 1.61 and 31.03 $\mathrm{mgkg}^{-1}$ with Maize/Millet having the least and Cocoyam LUTs having the highest value (Tables 4). When the mean values were averaged over each location, the mean at Shabu was $11.92 \mathrm{mgkg}^{-1}$ and $12.08 \mathrm{mgkg}^{-1}$ at Agyaragu. A critical range of 8 to $12 \mathrm{mgkg}^{-1} \mathrm{P}$ was reported for tropical soils (Enwezor et al., 1989). This shows that except for Banana/Plantain (14.98 $\left.\mathrm{mgkg}^{-1}\right)$ LUT in Agyaragu; Rice $\left(26.75 \mathrm{mgkg}^{-1}\right)$ and Cocoyam (31.03 $\mathrm{mgkg}^{-1}$ ) in Shabu, all other LUTs in both locations were P deficient. Phosphorus deficiency in tropical soils has been related to leaching by intense rainfall, high weatherability of the soils, presence of kaolinitic clay as the dominant mineral (Enwezor et al., 1989) and adsorption reaction by soil constituents (Bubba et al., 2003).

\subsection{Land use management relationship with soil properties}

Results in Table 5 show the interactions between the soil properties and land use management. The interaction was eithersignificant at $\mathrm{P}<0.01, \mathrm{P}<0.05$ or none. At Agyaragu, bulk density (Bd) interaction with Oil palm and Banana/Plantain LUTs management was highly significant $(\mathrm{P}<0.01)$, and Orange orchard $(\mathrm{P}<0.05)$.Other LUTs did not show significance for Bd. Significant correlations were found between Yam/Cassava $(\mathrm{P}<0.01)$, Cocoyam $(\mathrm{P}<0.05)$ and Fallow $(\mathrm{P}<0.05)$ management practices with Ksat. Soil textures varied in their levels of interactive significance with LUT management practices. However, sand significantly correlated with more LUT management practices than silt and clay at 0.05 and $0.01 \%$ levels of probability.

LUT management interactions did not show significance with soil $\mathrm{pH}$ except Maize/Cassava $(\mathrm{P}<0.01)$, Orange orchard and Banana/Plantain LUTs $(\mathrm{P}<0.05)$. Organic matter interaction was significantly $(\mathrm{P}<0.01)$ higher with Yam/Cassava and Cocoyam than with Maize/Cowpea $(\mathrm{P}<0.05)$. Other significant interactions include: total $\mathrm{N}$ with Maize/Cowpea and Oil palm $(\mathrm{P}<0.01)$; Yam/Cassava and Banana/Plantain at $\mathrm{P}<0.05$. Interaction of $\mathrm{CEC}$ with Maize/Cowpea and Oil palm was highly significant $(\mathrm{P}<0.01)$, while those of Yam/Cassava and Banana/Plantain were significant at $0.05 \%$ probability level.

Table 4: Chemical properties of soils under varying Land use types (LUT) at Agyaragu and Shabu locations.

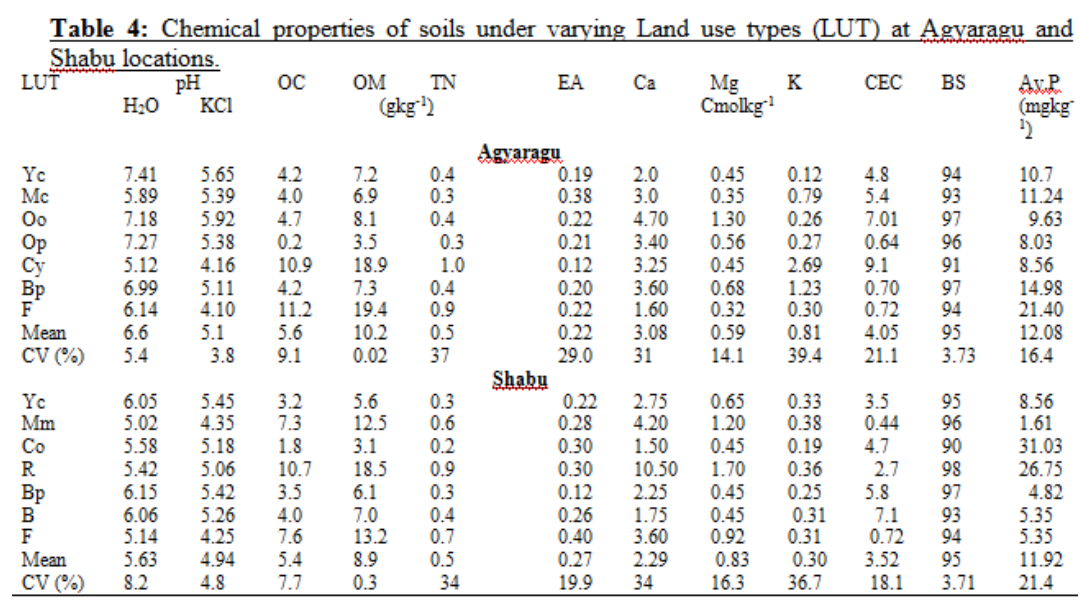

NB: $\mathrm{OC}=$ organic carbon, $\mathrm{OM}=$ organic matter, $\mathrm{TN}=$ total nitrogen, $\mathrm{EA}=$ exchangeable acidity, $\mathrm{Ca}=$ calcium, $\mathrm{Mg}=$ magnesium, $\mathrm{K}=$ potassium, $\mathrm{CEC}=$ cation exchange capacity, $\mathrm{BS}=$ base saturation, Av. $\mathrm{P}=$ available, phosphorus, $\mathrm{Yc}=\mathrm{yam} /$ cassava, $\mathrm{Mc}=$ maize/cowpea, $\mathrm{Oo}=$ orange orchard, $\mathrm{Op}=\mathrm{oil}$ palm, $\mathrm{Cy}=$ cocoyam, $\mathrm{Bp}=$ banana/plantain, $\mathrm{Mm}=$ maize/millet, $\mathrm{Co}=$ cashew/orange orchard, $\mathrm{R}=$ rice, $\mathrm{B}=$ bamboo, $\mathrm{F}=$ fallow, $\mathrm{CV}(\%)=$ coefficient of variation . 


\subsection{Soil degradation rate (SDR)/Vulnerability potential (Vp)}

Soil degradation rate (SDR) and Vulnerability potential of the soil qualities are presented in Table 6. In both locations, soil qualities varied in potentials for degradation (SDR) and are in the range: slight $(\mathrm{SDR}=2)$, moderate $(\mathrm{SDR}=3)$ and severe $(\mathrm{SDR}=4)$ corresponding to vulnerability potential range: low $(\mathrm{Vp}=$ 4), moderate $(\mathrm{Vp}=3)$ and high $(\mathrm{Vp}=2)$.

Table 5: Correlation coefficient between management practices in the land use types and selected soil properties at Agyaragu and Shabu locations.

\begin{tabular}{|c|c|c|c|c|c|c|c|}
\hline Variable & $\mathrm{Y} / \mathrm{C}$ & $\mathrm{M} / \mathrm{C}$ & Oo & Op & $\mathrm{Cy}$ & $\mathrm{B} / \mathrm{P}$ & $\mathrm{F}$ \\
\hline \multicolumn{3}{|c|}{ Soil physical Properties } & \multicolumn{5}{|l|}{ Agyaragu } \\
\hline $\mathrm{Bd}$ & 0.1201 & -0.2173 & $-0.4822^{* *}$ & $-0.4111^{*}$ & 0.1434 & $0.2433^{*}$ & -0.2218 \\
\hline Ksat & $-0.3354 *$ & 0.0161 & 0.1639 & 0.1111 & $-0.3743 * *$ & -0.2176 & $-0.2271^{* *}$ \\
\hline Clay & -0.2895 & $-0.4613^{* *}$ & 0.2268 & $-0.4211^{*}$ & 0.2740 & -0.1141 & $0.3201^{*}$ \\
\hline Silt & -1060 & -0.2974 & 0.2414 & $-0.3313^{*}$ & $0.3133^{* *}$ & $-0.3179 * *$ & -0.1904 \\
\hline Sand & $-0.3767^{*}$ & $0.4100^{* * *}$ & $0.3122^{*}$ & -0.1112 & -0.1001 & $-0.4112^{*}$ & $0.4512^{* *}$ \\
\hline \multicolumn{8}{|c|}{ Chemical Properties } \\
\hline SoilpH & -0.1091 & $-0.4111^{*}$ & $0.3600^{* *}$ & 0.2111 & -0.2090 & $0.3811^{* *}$ & 0.1119 \\
\hline $\mathrm{OM}$ & $-0.3097 *$ & $-0.4277^{* * *}$ & -0.1177 & 0.1381 & $-0.3111^{*}$ & 0.0113 & -0.1632 \\
\hline $\mathrm{TN}$ & $-0.4001^{* *}$ & $-0.1733^{*}$ & 0.1111 & $0.3551^{*}$ & -0.1830 & $-0.4119^{* *}$ & 0.3011 \\
\hline Av.P & $0.3774 *$ & $0.3660^{*}$ & $-0.4222 * *$ & 0.1021 & $-0.3002^{*}$ & 0.1000 & -0.1904 \\
\hline Exch. K & -0.2022 & 0.1661 & $-0.3391 *$ & $0.4990^{* * *}$ & 0.2227 & 0.1777 & $-0.3208^{*}$ \\
\hline $\mathrm{CEC}$ & $-0.4100 * *$ & $0.3117^{*}$ & -0.1100 & $0.3111^{*}$ & -0.1990 & $-0.4857^{* *}$ & 0.0833 \\
\hline BS & $-0.4333^{* *}$ & 0.2909 & $-0.3254^{*}$ & -0.277 & -0.1007 & 0.1935 & $0.3730^{*}$ \\
\hline \multicolumn{8}{|c|}{ Shabu } \\
\hline & $\mathrm{Yc}$ & $\mathrm{Mm}$ & $\mathrm{Co}$ & $\mathrm{R}$ & $\mathrm{Bp}$ & B & $\mathrm{F}$ \\
\hline \multicolumn{8}{|c|}{ Soil physical Properties } \\
\hline $\mathrm{Bd}$ & -0.3001 & -0.2393 & $-0.4121^{* *}$ & -0.2097 & $0.3784^{*}$ & 0.2433 & $-0.4250^{* * *}$ \\
\hline Ksat & $-0.3664^{*}$ & 0.3060 & 0.1097 & $0.4421^{* *}$ & $0.3003^{*}$ & $-0.4576^{* *}$ & -0.2271 \\
\hline Clay & $-0.3421^{* *}$ & 0.1666 & $0.3198^{* * *}$ & -0.0934 & -0.3130 & -0.1901 & 0.2433 \\
\hline Silt & -0.4112 & 0.2974 & -0.4114 & -0.1090 & $0.3133^{*}$ & -0.3179 & -0.1066 \\
\hline Sand & $0.3117^{*}$ & $-0.3100^{* * *}$ & -0.1102 & $-0.3441^{*}$ & -0.3011 & $-0.4109 * *$ & -0.2772 \\
\hline \multicolumn{8}{|c|}{ Chemical Properties } \\
\hline SoilpH & $-0.4019^{* * *}$ & -0.2096 & $-0.3550 *$ & -0.2120 & $-0.3300^{* *}$ & 0.3441 & $0.3044^{*}$ \\
\hline $\mathrm{OM}$ & $0.3417^{* * *}$ & $-0.3069 *$ & 0.4037 & $0.3611^{*}$ & $-0.3111^{* *}$ & 0.1182 & -0.3208 \\
\hline $\mathrm{TN}$ & -0.1154 & $-0.4093^{* *}$ & $0.3071^{*}$ & $-0.3221 * *$ & -0.1830 & $-0.4102^{* *}$ & 0.1116 \\
\hline Av.P & $0.3753^{*}$ & $0.3260^{*}$ & -0.2006 & $0.4009^{* *}$ & $-0.3002^{*}$ & -0.2901 & -0.4460 \\
\hline Exch. K & -0.2172 & $-0.4901^{* * *}$ & -0.3841 & $-0.3190^{*}$ & 0.2227 & $0.4947^{* *}$ & $-0.4018^{* *}$ \\
\hline $\mathrm{CEC}$ & $-0.4207^{* * *}$ & 0.1400 & $-0.3926 * *$ & $0.1003^{*}$ & -0.1990 & $-0.3731^{*}$ & 0.2103 \\
\hline BS & $-0.3059 *$ & $0.4709^{* *}$ & -0.3044 & -0.1877 & -0.1007 & $-0.3265^{*}$ & $-0.4110^{* * *}$ \\
\hline
\end{tabular}

$\mathrm{NB}$ : $\mathrm{BD}=$ bulk density, Ksat= saturated hydraulic conductivity, $\mathrm{OM}=$ organic matter, $\mathrm{TN}=$ total nitrogen, Exch $\mathrm{K}=$ exchangeable potassium, $\mathrm{CEC}=$ cation exchange capacity, $\mathrm{BS}=$ base saturation, Av. $\mathrm{P}=$ available phosphorus, $\mathrm{Y} / \mathrm{C}=\mathrm{yam} /$ cassava, $\mathrm{M} / \mathrm{C}=$ maize $/$ cowpea, $\mathrm{Oo}=$ orange orchard, $\mathrm{Op}=$ oil palm, $\mathrm{B} / \mathrm{P}=$ banana/plantain, $\mathrm{C} / \mathrm{O}=$ cashew/orange orchard, $\mathrm{Cy}=$ cocoyam, $\mathrm{F}=$ fallow, ${ }^{* *}=$ significance at $0.05 \%, *=$ significance at $0.01 \%$

Results in Table 6 indicate that soil $\mathrm{pH}$ has none or minimal risk of soil degradation $(\mathrm{SDR}=1 ; \mathrm{Vp}=5)$ at Agyaragu than slight risk at $\mathrm{Shabu}(\mathrm{SDR}=2 ; \mathrm{Vp}=4)$. This implies that soil $\mathrm{pH}$ at Agyaragu is a better quality than that at Shabu that hasslightly more potential vulnerability to erosion. This corresponds to mean soil $\mathrm{pH}$ values (Shabu- 5.63; Agyaragu- 6.6; Table 4).In both locations, the respective SDR/Vp of SOM (4/2), total N (4/2), and CEC (4/2) suggests severity, implying high susceptibility to degradation. The SDR and Vp value for available $\mathrm{P}$ was 3 , indicating moderate potential degradation or vulnerability.

The principle that "good soil quality has least SDR and poor soil quality has the highest SDR and vice versa for Vp" implies from Table 6 that soil properties and their relationship with SDR/Vp are of the decreasing order: $\mathrm{pH}\left(\mathrm{H}_{2} \mathrm{O}\right)(\mathrm{SDR}=1 ; \mathrm{Vp}=5)>$ bulk density and Ksat $(\mathrm{SDR}=2 ; \mathrm{Vp}=4)>$ texture and available $\mathrm{P}(\mathrm{SDR}=$ $3 ; \mathrm{Vp}=3)>\mathrm{SOM}$, total $\mathrm{N}$ and $\mathrm{CEC}(\mathrm{SDR}=4 ; \mathrm{Vp}=2)$. The soils at Ayaragu appears to be slightly more capable to resist degradation (mean SDR = 3.0) than Shabu soils with mean SDR of 3.4. 
Table 6: Rating scheme for degradation rates (SDR) and vulnerability potential (Vp) of the selected soil qualities in the study locations.

\begin{tabular}{lcc}
\hline Parameters & \multicolumn{2}{c}{ Location } \\
\cline { 3 - 3 } Soil Physical properties & Agyaragu & Shabu \\
\hline Bulk density $\left(\mathrm{Mgm}^{-3}\right)$ & $2(4)$ & $2(4)$ \\
Ksat $\left(\mathrm{Cmhr}^{-1}\right)$ & $2(4)$ & $2(4)$ \\
Texture & $3(3)$ & $3(3)$ \\
Chemical properties & & \\
Soil pH $\left(\mathrm{H}_{2} \mathrm{O}\right)$ & $1(5)$ & $2(4)$ \\
Organic matter $\left(\right.$ gkg- $\left.^{1}\right)$ & $4(2)$ & $4(2)$ \\
Total $\left(\right.$ gkg- $\left.^{1}\right)$ & $4(2)$ & $4(2)$ \\
CEC $\left(\mathrm{Cmolkg-}{ }^{1}\right)$ & $4(2)$ & $4(2)$ \\
Av.P $\left(\mathrm{Mgkg}^{-}{ }^{-}\right)$ & $3(3)$ & $3(3)$ \\
\hline
\end{tabular}

NB: $1=$ none, 2 = slight, $3=$ moderate, $4=$ severe, $5=$ extreme for SDR. Values in bracket represent vulnerability potential as none $=5$, low $=4$, moderate $=3$, high $=2$, very high $=1$. Ksat $=$ saturated hydraulic conductivity, $\mathrm{CEC}=$ cation exchange capacity, $\mathrm{N}=$ nitrogen, Av.P = available phosphorus. Ratings based on mean soil quality and critical limits established critical levels of soil elements from various literatures (Adepetu et al., 1979; Adeoye et al., 1984; Landon, 1984; Enwezor et al., 1989; Isirimah et al., 2003; Lal, 1994).

\section{Conclusions}

Results of this study revealed that spatial variability of soils under different land use types and their soil property vulnerability potentials or degradation rates can be evaluated in a savanna agroecology. The study showed that the land use types were located between upland, midland and lowland physiographies. The management practices spatially varied with the kind of land use. Soil information results indicated that the physicochemical properties varied within the various LUTs and the land uses did not affect the soil texture, being predominantly sandy loam in both locations, an evidence of similarity in lithological origin. Silt/clay ratio also varied spatially within the LUTs from less than unity to greater than unity, suggesting degrees of weatherability. Bulk density values varied between low and high corresponding respectively to high and low water transmisivity of Ksat.

Soil chemical property results revealed spatial variations from one location to another and within the LUTs. The correlations showed that at Agyaragu, 23 LUT management practices and soil properties correlated at $0.01 \%$, while 18 were significant at $\mathrm{P}<0.05$. At Shabu 24 LUT management practices were significant at $\mathrm{P}<0.05$ and 19 at $\mathrm{P}<0.01$. Based on these analyses, LUT management practices relatively but significantly correlated higher $(\mathrm{P}<0.01)$ with soil properties at Agyaragu than at Shabu $(\mathrm{P}<0.05)$.

The various vulnerability potentials or degradation risks showed best soil qualities in a decreasing order of $\mathrm{pH}\left(\mathrm{H}_{2} \mathrm{O}\right)>$ bulk density and Ksat $>$ texture and available $\mathrm{P}>\mathrm{SOM}$, total $\mathrm{N}$ and CEC. Best soil quality appears to be soil $\mathrm{pH}$ with SDP/Vp value of 1 or 5, while the least had a value of 5 or 1 for SDR or Vp. The LUT soils at Ayaragu have more tendency to resist degradation (mean SDR $=3.0$ ) than those of Shabu (mean SDR $=3.4$ ), suggesting higher input management.

\section{Recommendations}

The low nutrient contents observed in the two location soils could be increased through organic farming mulching and returning crop residues (trash farming) to the soils and this would benefit the farmers. The World Bank in 2002 launched a $\$ 100$ million Biocarbon Fund to provide finance to projects that store carbon in vegetation and soils while trying to reverse land degradation, conserve biodiversity and improve the livelihoods of local communities (Newcombe, 2003). Furthermore, the World Bank (2003) launched the Community Development Carbon Fund to provide carbon finance to small scale projects in the least-developed countries. Local communities within the savanna agroecology can potentially benefit from these funds by increasing their soil carbon stocks.

Farmers need early warning signals and monitoring tools to help them assess the status of their soils since most farming soils in the savanna agro-ecology were vulnerable to erosion (wind or water) and by the time degradation becomes visible and irreversible, it might be too late or very expensive to reverse it. Creating and using bio-physical and chemical data bank is very important and could be achieved through detailed soil survey and land evaluation activities.

With regards to land use planning, most of the marginal land use systems are necessary to be converted fundamentally from arable to agro-forestry. Land use changes to intensively tilled agricultural cultivation are one of the reasons for soil fertility degradation. Therefore aforestation programs as well as application of biochars should be encouraged. 
In terms of land use management, an agricultural land management analysis must be a second phase after the land use planning for soil protection. Any kind of agricultural management will have environmental impact when applied on lands with very low suitability to agricultural uses. The land management decisions should aim more at farm level than at policy development, establishing the set of agricultural practices that are possible in each soil with high acidity. Subsidization of agricultural inputs by governments can assist farmers apply agricultural limes.

Inappropriate tillage practices accelerate the soil fertility degradation processes, especially soil erosion and compaction. To formulate the tillage system for each agricultural land is a critical point to combat the soil erosion problem in the agricultural lands. Tillage direction: up and down slope, and along the contour; tillage intensity: conventional tillage, reduced tillage, ploughless tillage, minimum tillage, and no-tillage; and tillage implement type: chisel plow, disk, and cultivator, are the major issues to define the tillage system.

\section{Acknowledgement}

The author remains grateful to the Associate and Federation Scheme of the Abdu Salem International Centre for Theoretical Physics (ICTP), Trieste, Italy for providing me (as a Regular Associate) Library and Computer facilities that aided the completion of this study.

\section{References}

[1]. J.A.Adepetu, A.A., Adebayo, E.A.Aduayi, and G.O Alofe. A preliminary survey of the fertility status of soils in Ondo state under traditional cultivation. Ife J. Agric.1, 1979, 134-149.

[2]. G.O Adeoye, and A.A Agboola. Critical levels for soil pH, available P, K, Zn and Mn and maize ear-leaf content of P, Cu and Mn in sedimentary soils of south-west Nigeria. Fertilizer Res. 6, 1985, 65-75

[3]. A.A.Agboola, and R.B.Correy.. Nutrient efficiency survey of maize in western Nigeria. Nig. J Sci.10, 1976, 1-18

[4]. H.A.,Akintola,E.O.,Lucas, andJ.G. King. Effects of density of planting and time of N application in maize varieties in different ecological zones of West Africa Common Soil. Sci. Plant Analysis 28 (13 \& 14), 1997, 116-175.

[5]. E.A.Akinrinde, andG.O. Obigbesa. Evaluation of fertility status of selected soils for crop production in Five ecological areas of Nigeria. Proc. $26^{\text {th }}$ Ann. Conf. Soil Sci. Soc. Nig., Ibadan, Oyo State., 2000, 79-453

[6]. Areola. Soil variability within land facets in areas of low smooth relief: a case study on the Gwagwa Plains, Nigeria. Soil Survey and land Evaluation 2(1), 1982, 9-13

[7]. C.L.A. Asadu. Comparative land evaluation of yam-zone soils and the performance of six cultivars of white yam (D. rotundata) in southesatern Nigeria. PhD thesis, University of Nigeria, Nsukka, Nigeria. 1979, 420pp.

[8]. C.L.A. Asadu, and A.A. Enete. Food crop yields and soil properties under population pressure in SS Africa. The case of cassava in southesatern Nigeria. Outlook on Agriculture, 26 (1), 1990, 29-34.

[9]. P.H.T. Beckett, and R. Webster. Soil variability: A review. Soil Fert. 34, 1971, 1-5

[10]. J.W. Bigger,and D.K. Nielson. Spatial variability of the leaching characteristics of a field soil. Water Resources Res, 12, 1976, 7884.

[11]. Bremmer, J.M and Mulvaney, C.S (1982). Total N, P. 895-926. In: Page et al (eds) Methods of Soil Analysis. Part2. $2^{\text {nd }}$ ed. Agron. onog. 9. ASA and SSSA, M adison WI.

[12]. M.O. Bubba, C.A., Arias, and H. Briax. Phosphorus adsorption maximum of sands for use as media in subsurface flow cultivate dreed beds as measured by Langmuir isotherm. Water Res. 39, 2003, 3390-2400.

[13]. M.A. Busari,F.K, Salako,R.A, Sobulo, M.A. Adetunji,and N.J.Bello. Variation in soil pH and maize yield as affected by the application of poultry manure and lime. In: Managing Soil Resources for Food and Sustainable Environment. Proc. $29^{\text {th }}$ Ann. Conf. Soil Sci. Soc. Nig., 2005, 139-142.

[14]. J. Caron,B.O. Kay,and J.A. Stone. Improvement of structural stability of a clay loam with drying. Soil Sci.Soc. Am. J., 56, 1992, $1583-1590$

[15]. L.J. Chicacek, and M.J. Ulmer, M.J. Effects of tillage on inorganic carbon distribution in soils of the northern Great Plains of the US. In: Agricultural practices and policies for carbon sequestration in soils. An Int. symp. 19-23 July, 1999. Wexner Center for the Arts. The Ohio State University.

[16]. H.P.Collins,R.L.Blevins,L.G. Bundy,D.R.Christenson, W.A. Dick,D.R. Huggins, and E.A. Paul. Soil carbon dynamics in cornbased agroecosystems: results from carbon-13 natural abundance. Soil Sci. Soc. of Amer. J, 63 (3), 1999, $584-591$.

[17]. D. de la Rosa, F. Mayol,W.R. Diaz-Pereire,M. Ferndez, and D. de la RosaD Jr.A land evaluation decision support system (Micro-LEIS DSS) for agricultural protection with special reference to the Mediterranean region. Env. Modelling and Software 19, 2003, 929-942.

[18]. J.W. Doran, and T.B. Parkin. Defining and assessing soil quality. In: Doran J.W et al eds, Defining soil quality for sustainable environment. Soil Sci. Soc. of Amer Special publication \# 35, Madison, WI, 1994, 3-21.

[19]. D.M. Ekpete. Comparison of methods of available K assessment for eastern Nigerian soils. Soil Sci: 113, 1972, 213-221

[20]. W.O. Enwezor,A.C. Ohiri,E.E. Opuwaribo, E.J. Udo. Review of fertilizer use on crops in Southeastern Nigeria. Fertilizer Procurement and Distribution, Lagos, Nigeria, 1989, .420pp.

[21]. P.I. Ezeaku. Evaluation of legume crops as alternative source of fertilizer for maize production in Abakaliki, Southeastern Nigeria, Journal of Agriculture, Technology and Extension, 2 (2), 2001, 30-38.

[22]. P.I. Ezeaku,F.O.R. Akamigbo, and C.L.A. Asadu. Maize Yield Predictions based on soilfertility parameters in Southeastern Nigeria, Journal of Agro-Technology and Extension, 6 (3), 2002, 1-10.

[23]. P.I. Ezeaku, andE.S.Salau. Indigenous and scientific soil classification systems: Acase of differences in criteria in some soils of northcentral Nigeria. Production Agriculture and Technology Journal. 1(1), 2005, 54-66

[24]. P.I. Ezeaku, and M.A.N.Anikwe,. A model for description of water and solute movement in soil-water restrictive horizons across two landscapes in South-East Nigeria. Journal of Soil Science 171(6). 2005, 492-500

[25]. P.I. Ezeaku,and D. Alaci. Analytical situations of land degradation and sustainable management strategies in Africa. Pakistan Journal of Agriculture and Social Sciences. 4, 2008, 42-52. http://www.fspublishers.org

[26]. A.S. Fasina. Variability of maize yield and some soil properties in an exhaustively cultivate field in the school of Agriculture, Ikorodu. Pertanika Trop. Agric. Sci. 25 (1), 2002, 11-17 
[27]. G.W. Geeand J.W. Bauder. Particle Size Analysis. 1986, 383-411. In: Klute,A (ed). Methods of Soil Analysis. Part2. $2^{\text {nd }}$ ed. Agron. Monog. 9. ASA and SSSA, Madison, WI.

[28]. J.J. Hanway. Corn growth and composition in relation to soil fertility. I. Growth of different plant parts in relations between leaf weight and grain yield. Agronomy Journal 54, 1992, 145-148.

[29]. R.A. Hushman. Statistical methods for environmental and agricultural sciences. $2^{\text {nd }}$ ed. CRC Press. 1997, 460pp.

[30]. N.O.Isirima, , C. Igwe, and M.A. Ai. Important ions in soil environment. In: ISIRIMA, N.O., A.A. DICKSON and C IGWE (Eds.) Introductory soil chemistry and biology for Agriculture and Biotechnology. 2003, 34-97.

[31]. B.T.Kang. Effect of some biological factors on soil variability in the tropics: III. Effect of macrotermes mounds. Plant \& Soil 50, 1978, 241-251.

[32]. R. Lal. Tropical soils: distribution, properties and management. Resources Management and Optimization. 7, $1990,39-52$.

[33]. R. Lal.Methods and guidelines for assessing sustainability use of soil and water resources in the tropics. Soil Management Support Services technical monograph \#21, 1994, 1-78.

[34]. F.R. Moorman and B.T. Kang. Microvariability of soils in the tropics and its agronomic implications with special reference to West Africa. In: diversity of soils in the tropics. ASA special Publ, 34, 1978, 29-43.

[35]. E.O. McLean. Soil $\mathrm{P}^{\mathrm{H}}$ and Lime Requirement. 1982, 199-224. In: Page et al (eds) Methods of Soil Analysis. Part2. chemical and microbial properties. $2^{\text {nd }}$ ed. Agron. Monog. 9. ASA and SSSA, Madison, WI

[36]. L.G. Lombin. Assessment of the magnesium potentials in some Nigerian soils. 1974 PhD thesis, Agronomy Dept. University of Ibadan, Nigeria.

[37]. G.I. Levy and W.P. Miller. Aggregate stability of some southern US soils. Soil Sci. Soc. of Amer. J, 61, 1997, 1176-1182.

[38]. C. Neil,J.M. Melillo,P.A. Steudler,C.C. Lerri,J.F.L. Demoraes,M.C. Picolo,and M. Brito. Soil carbon and nitrogen stock following forest clearing for pasture in the southwestern Brazilian Amazon, Ecological Applications, 7(4), 1997, 1216-1225.

[39]. D.W. Nelson, and L.E.Sommers. Total carbon, organic carbon and organic matter. 1982, 539-579. In: PAGEet al (eds) Methods of Soil Analysis. Part2. $2^{\text {nd }}$ ed. Agron.Monog. 9. ASA and SSSA, Madison, WI.

[40]. K.J. Newcombe. Extending the carbon market to the world's poor, the World Bank. ABCDE, Paris. 2003 and accessed on 9/14/2004rom http://wblIn0018.worldbank.org/eurvp/web.nsf/pages.pare+by+newcombe/\$file/ACDE+KEN+NEWCOM BE+REV ISED.PDF

[41]. S.S. Noma,A.G. Ojanuga,S.A. Ibrahimand M.A. Iliya. Detailed soil survey of Sokoto-Rima flood plain at Sokoto. In: Managing oil resources for food security and sustainable management. Proc. $29^{\text {th }}$ Ann. Conf.Soil Sci. Soc. Nigeria. In: Uzoho, B.U, Oti, N.N and A. Ngwuta, 2007. Fertility rates under land use types on soils of similar lithology. Journal of American Sci. 3(4), 2005, 20-29.

[42]. G.K. Nwaka and J.J. Kwari. The nature and properties of the soils of Jere Bowl near Maiduguri in Borno State. Samara J. Agric \&Res. 16, 2000, 25-40.

[43]. N.G. Obaje,A.I. Nzegbnam, A., Moumouni and C.E. Ukaonu. Geology and Mineral Resources of Nasarawa State, Nigeria. A preliminary Investigation. Paper presented at the $4^{\text {th }}$ Nasarawa State Agricultural and Solid Minerals Exposition held at Agyaragu, Nasarawa State, Nigeria, , 21-23 March, 2005, 1-27.

[44]. A.O. Ogunkunle. Spatial variability of some chemical properties in two Ultisol mapping units in southern Nigeria. Soil Survey \& Land Evaluation 6, 1986, 26-32.

[45]. A.G. Ojanugaand A.I.Awojuola. Characteristics and classification of the soils of the Jos plateau, Nigeria. Nig. Soil Science, 10, 1981, 101-119.

[46]. G.W. Olson. Yield correlation. Soil and Environmental. A dowin and Guller Books, Chapman and Hall, NY. London, 1981, 119129.

[47]. S.R. Olson and L.E. Sommers. Phosphorus. 1982, 403-434. In: Page et al (eds) Methods of Soil Analysis. Part2. $2^{\text {nd }}$ ed. Agron. Monog. 9. ASA and SSSA, Madison, WI.

[48]. O.A. Opara-Nadi. Liming and organic matter interactions in two Nigerian ultisols on soil pH, OC and early growth of maize (zea mays. L). In: Uzoho, B.U, Oti, N.N and A. Ngwuta, 2007. Fertility rates under land use types on soils of similar lithology. Journal of American Sci. 3(4), 1998, 20-29.

[49]. M.M.Pando, E.Jurodo,M. Manzano and E. Estrada. The influence of land use on desertification process. Journal of Range management, 57(3), 2004, 320-340.

[50]. SAS Institute, 2000. SAS Procedures Guide. Release 8 Edition, SAS, Cary, NC

[51]. R. Scalenge,G. Certini,E.Cortini, E.Zanani,and F.C. Ugolini. Segregated ice and liguefaction effects on compaction of fragipans. Soil Sci. Soc. of Amer. J, 68, 2004, 204-214.

[52]. R.C. Swartz,P.W. Unger and S.R. Evelt. Land use effects on soil hydraulic properties. Cons. \& Production Res. 2003. Lab.USDAARS

[53]. W. Tamilson. Variations in usefulness of rapid soil mapping in the Nigerian savanna. J.Soil Sci 21, 1970, $162-172$.

[54]. G.W. Thomas. Exchangeable cations, 1982, 159-165. In: Page et al (eds) Methods of Soil Analysis.

[55]. Part2. $2^{\text {nd }}$ ed. Agron. Monog. 9. ASA and SSSA, Madison, WI.

[56]. B.U.Uzoho,N.N. Oti, and A. Ngwuta. Phosphorus adsorption characteristics of selected southeast Nigerian soils. J.Agric and Social Res, 5(2),2003, 55-60.

[57]. B.U.Uzoho,N.N. Oti, and A. Ngwuta. Fertility rates under land use types on soils of similar lithology. Journal of American Sci. 3(4): 20-29.

[58]. White, J.R and Reddy, K.R(1999). Influence nitrate and phosphorus loading on denitrifying wetland soils. Soil Sci. Amer.J. 63, 2007, 1945-1954.

[59]. R.A. Wooding. Steady infiltration from a shallow pond. Water Res. Research, 4, 1968,1259-1273 